\title{
MAKNA PARIWISATA PULAU KEMARO MENURUT PENGUNJUNG DAN PERILAKU KOMUNIKASINYA
}

\author{
Studi Fenomenologi Mengenai Pemaknaan Pariwisata Pulau Kemaro oleh Pelancong Budaya dan \\ Pelancong Religi Pariwisata Pulau Kemaro di kota Palembang \\ Dwi Maharani \\ Universitas Bina Darma
}

\begin{abstract}
ABSTRAK
Penelitian ini memiliki tujuan untuk mengkaji dan menjelaskan bagaimana pengunjung memaknai Pariwisata Pulau Kemaro dan mengetahui bagaimana perilaku komunikasi pengunjung pariwisata pulau Kemaro. Metode penelitian yang digunakan adalah kualitatif, dengan pendekatan fenomenologi. Subjek penelitian terdiri dari enam orang informan yang terdiri dari 3 orang pelancong budaya dan 3 orang pelancong religi yang diambil secara purposive. Hasil dari penelitian menunjukkan, pengunjung pariwisata pulau Kemaro yang merupakan informan pada penelitian ini memberikan pemaknaan terhadap pariwisata pulau Kemaro berdasarkan pandangan subjektif. Sehingga informan dalam penelitian memberikan pemaknaan yang beragam terhadap Pariwisata Pulau Kemaro. Hasil penelitian menunjukkan bahwa komunikasi mewarnai semua aspek yang ingin diketahui, baik dari segi pandangan, pengalaman, dan motif pada setiap pengunjung. Pengunjung memberikan pandangan terhadap Pariwisata Pulau Kemaro sebagai tempat bersejarah, tempat yang nyaman, dan juga tempat untuk sembahyang. Pengalaman yang dirasakan pelancong selama berada di pulau Kemaro berkaitan dengan kegiatan festival budaya, perayaan 17 Agustusan, perjalanan menuju Pulau Kemaro, sembahyang, sampai dengan pengalaman mengenai penyembuhan penyakit. Sedangkan motif yang dimiliki pelancong, yaitu untuk mencari ketenangan dan kesenangan, ajakan dari orang terdekat (orangtua ataupun teman), untuk melakukan kegiatan keagamaan, ketertarikan pelancong pada sejarah pariwisata pulau Kemaro, serta motif untuk berkumpul bersama anggota keluarga. Perilaku komunikasi yang terjadi yaitu dalam bentuk interaksi diantara pengunjung serta pengunjung dengan pelaku wisata yang menggunakan komunikasi verbal. Kesimpulan dari penelitian tentang makna pariwisata pulau Kemaro menurut pengunjung yaitu sebagai tempat warga Tionghoa untuk sembahyang, dan salah satu tempat wisata yang memiliki nilai sejarah yang tinggi dan nyaman yang ada di kota Palembang.
\end{abstract}

Kata-kata kunci: Makna pariwisata, perilaku komunikasi, Pulau Kemaro, Palembang

\section{THE MEANING OF KEMARO ISLAND TOURISM ACCORDING TO VISITORS AND THEIR COMMUNICATION BEHAVIOR}

\begin{abstract}
Research aim's to assess and explain on how visitors, interpret tourism activities at the Kemaro Island, and to find out how the communication behavior at Kemaro island among these tourists. This research uses qualitative methods with phenomenological approach. Research subjects consist of six informants; with 3 cultural travelers and 3 religious travelers taken purposively. The result shows that, travelers of Kemaro island (the informants) gives meaning to the island tourism based on subjective views. Thus there are multiple meanings to the Island Tourism Kemaro coming out from research informants. The results show that the aspects of the communication illuminate all element that researcher want to know on this study. This can be seen both from the views, experiences, and patterns on every visitor. The views on Kemaro Island Tourism are as a historic place, a comfortable place, and a place to hold a prayer. Travelers experience gained at the island Kemaro is associated with prayer, cultural festivals, August 17 celebrations, and the journey to the Kemaro Island, as well as the healing of a disease. While the motives of the travelers are to seek tranquility and pleasure, getting an invitation from the relatives (parents or friends), religious activities, interest in history, and to meet family members. Communication behaviors that occur are in the form of interaction among the visitors, and visitors with person involved in tourism through verbal communication. Conclusion of the research is that the meaning of tourism of the island are a place for Chinese community to worship, and one of the tourist attractions in Palembang that has a convenience and high historical value.
\end{abstract}

Keywords: Meaning of tourism, communication behavior, Kemaro Island, Palembang

Korespondensi: Dwi Maharani, M.I.Kom. Universitas Bina Darma, Jln. A Yani No 12 Palembang, Sumatera Selatan.Email: dwimaharani2@yahoo.co.id 


\section{PENDAHULUAN}

Pulau Kemaro memiliki keunikan-keunikan tersendiri apabila dibandingkan wisata alam lainnya yang ada di kota Palembang atau pun tempat wisata lainnya di Provinsi Sumatera Selatan. Pulau Kemaro merupakan satu-satunya pulau yang ada di Kota Palembang, dan satu-satunya pulau yang menjadi tempat wisata di Kota Palembang. Pulau ini juga memiliki nama yang unik yaitu Pulau Kemaro yang berarti pulau yang tidak pernah tergenang air meskipun sungai sedang pasang, sehingga dari kejauhan pulau tersebut akan terlihat terapung-apung di atas perairan sungai Musi. Pulau ini juga kerap kali disebut sebagai Pulau Cinta (jodoh), karena di dalam Pulau Kemaro terdapat sebuah pohon beringin (atau disebut pohon cinta). Konon, jika seseorang menuliskan nama dirinya dan pasangannya di pohon cinta, maka jalinan cinta mereka akan langgeng, dan yang belum memiliki pasangan, jika menuliskan namanya dan orang yang disukai, maka suatu saat nanti akan menjadi sepasang kekasih. Hal ini dapat dilihat dari banyaknya nama yang terukir pada pohon tersebut.

Selain pohon cinta, terdapat juga klenteng (Soei Goeat Kiong) yang dibangun sekitar tahun 1839, patung Budha yang berukuran besar, dan sebuah pagoda 9 lantai setinggi 40 meter yang menambah keindahan Pulau Kemaro. Pagoda tertinggi di kota Palembang ini juga menjadi penanda atas keberadaan Pulau Kemaro.

Menurut Erna dan Zaky yang merupakan pengunjung pariwisata Pulau Kemaro, menyatakan bahwa mereka senang datang ke Pulau Kemaro. Hal ini terlihat dari pernyatan mereka berikut ini:

Io, lemak maen kesini, beda dari tempat wisata lainnyo di Palembangni. Dijingok dari bangunannyo jugo unik, apolagi pagodanya bagus untuk tempat befoto, suasananyo nyaman untuk tempat bekumpul samo kawan-kawan sambil nyingok sungai Musi, kata Zaky.

Selain mengiyakan ucapan Zaky, Erna juga menambahkan:

Kami jugo seneng nian naek getek pas dateng kesini (Pulau Kemaro) yuk, jadi seru rame-rame dengen kawan.

Di Pulau Kemaro, terdapat sebuah tempat keramat yang merupakan makam seorang Puteri Palembang yang bernama Siti Fatimah dan suaminya Tan Bun Ann, seorang saudagar dari negeri Cina.

Berdasarkan kisahnya yang terukir di batu yang ada di Pulau Kemaro, diceritakan: Ada legenda seorang putri raja bernama Siti Fatimah yang disunting oleh seorang saudagar Tionghoa yang bernama Tan Bun An pada zaman kerajaan Palembang, Siti Fatimah diajak kedaratan Tiongkok untuk melihat orang tua Tan Bun An setelah di sana beberapa waktu Tan Bun An beserta istri pamit pulang ke Palembang dan dihadiahi 7(tujuh) buah guci, sesampai di perairan musi dekat Pulau Kemaro Tan Bun An mau melihat hadiah yang diberikan. Begitu di buka Tan Bun An kaget sekali isinya sawi-sawi asin, tanpa banyak berpikir langsung dibuangnya ke sungai, tapi guci yang terakhir terjatuh dan pecah di atas dek perahu layar. Ternyata ada hadiah yang tersimpan di dalamnya, Tan Bun An tidak banyak berpikir Ia langsung melompat ke sungai untuk mencari guci-guci tadi, seorang pengawal juga terjun untuk membantu. Melihat 2 (dua) orang tersebut tidak muncul, Siti Fatimah pun ikut lompat untuk menolong. Ternyata tiga-tiganya tidak muncul lagi, penduduk sekitar pulau sering mendatangi Pulau Kemaro untuk mengenang 3 (tiga) orang tersebut dan tempat tersebut dianggap sebagai tempat yang sangat keramat sekali.

Pulau Kemaro disebut-sebut sebagai makam ke tiga orang tersebut, karena sebelum ikut melompat untuk menolong, Siti Fatimah sempat berkata kepada pengawalnya: "Jika ada tanah yang tumbuh di tepi sungai ini maka di situlah kuburan saya." Ternyata benar, selang beberapa waktu lamanya, dari bawah sungai disekitar tempat mereka terjun muncul gundukan tanah yang diyakini sebagai makam Siti Fatimah, Tan Bun An dan sang pengawal, yang akhirnya tempat ini sekarang disebut sebagai Pulau Kemaro.

Awal kemunculannya, pulau ini hanya memiliki panjang sekitar $1 \mathrm{~km}$ dan lebar seluas $700 \mathrm{~m}$. Saat ini luas pulau ini kurang lebih 24ha (Palembang, 2013). Tidak hanya digunakan oleh etnis 
Tionghoa sebagai tempat untuk bersembahyang (wisata religi) tetapi Pulau Kemaro saat ini juga merupakan salah satu tempat wisata budaya di kota Palembang.

Pulau ini terletak di sebelah timur Kota Palembang, kira-kira $5 \mathrm{~km}$ ke hilir Jembatan Ampera. Sungai Musi yang mengalir ditengah-tengah kota Palembang memiliki banyak kisah dan legenda yang berkembang di masyarakat Palembang secara turun-temurun. Wajar saja hal ini terjadi, sebab bagaimana pun berabad-abad yang lalu hingga saat ini sungai Musi tidak terlepas dari kehidupan manusia. Baik sebagai jalur transportasi maupun sebagai jalur perekonomian. Pulau Kemaro merupakan salah satu titik penting dalam sejarah perkembangan Kota Palembang, sebagai salah satu emperium besar di Asia Tenggara (Palembang, 2013).

Banyak pengunjung yang berdatangan ke Pulau Kemaro saat ini, baik pengunjung lokal maupun pengunjung mancanegara, baik sebagai tempat wisata budaya maupun wisata religi. Peningkatan pengunjung sangat terlihat pada perayaan Cap Go Meh, pengunjungnya mencapai puluhan ribu orang. Khususnya untuk perayaan tahun baru Imlek 2564 atau tahun 2013 pada penanggalan masehi, pengunjung yang datang mencapai delapan puluh ribu orang (Palembang, 2013).

Pesona Pulau Kemaro tidak hanya menarik bagi etnis Tionghoa tetapi juga bagi warga etnis lain. Mereka datang ke Pulau Kemaro untuk berwisata dan sembahyang. Serta perilaku komunikasi yang terjadi di Pulau Kemaro juga sangat menarik karena terdapat beragam etnis yang berkunjung ke Pulau Kemaro.

Sarana transportasi yang biasa digunakan untuk menuju pulau ini juga terbilang unik. Sarana yang digunakan adalah transportasi air seperti Getek, Speed Boad dan bus air dari dermaga wisata Benteng Kuto Besak. Waktu yang dibutuhkan untuk sampai ke pulau ini sekitar 30 menit. Pada saat musim hujan, dan air sungai Musi sedang pasang masih banyak pengunjung yang berdatangan ke pulau ini.

Khusus pada perayaan Imlek, selama dua hari berturut-turut pengunjung tidak perlu menggunakan transportasi laut. Pengunjung dapat melalui jalur darat dengan berjalan di atas tongkang yang telah disusun dari pabrik Intirub menuju Pulau Kemaro (tongkang tersebut me- rupakan sumbangan/ pinjaman dari umat).

Berdasarkan pengamatan yang sempat peneliti lihat, serta didukung oleh data dari surat kabar Sumatra Ekspres (Sabtu, 23 Februari 2013), yang menyatakan bahwa pengunjung Pulau Kemaro yang datang mencapai delapan puluh ribu orang. Juga didukung dari hasil wawancara informal yang peneliti lakukan terhadap salah satu pelaku wisata Pulau Kemaro, yaitu Bapak Ikin (pemilik perahu Getek) yang mengantarkan pengunjung pulang pergi dari Jembatan Ampera ke Pulau Kemaro dan sebaliknya, yang mengatakan:

Yomasihjalan terus dek, biasonyo tiap haritu pasti ado, empok musim ujan jugo masih banyakyangdatangkesano(PulauKemaro.

Berdasarkan pernyataan tersebut telah diketahui, meskipun dimusim penghujan, perahu masih tetap beroperasi karena masih ada pengunjung yang ingin berwisata ke Pulau Kemaro.

Banyaknya hal menarik dan pesona yang begitu besar yang dimiliki Pulau Kemaro sehingga mampu menarik pengunjung untuk datang ke Pulau tersebut. Pulau kemaro bagaikan sebuah magnet yang mampu menarik siapa saja. Pesonanya membuat orang ingin datang, dan orang yang pernah datang ingin datang kembali.

Dari hasil pengamatan-pengamatan langsung yang tertangkap oleh peneliti di lapangan dan berdasarkan pemaparan di atas, muncul pemikiran bahwa banyak pengunjung dari beragam etnis yang datang ke Pariwisata Pulau Kemaro. Bahkan ada juga yang datang lebih dari dua kali ke pulau ini, meskipun tidak mudah untuk dapat mencapai tempat ini, dan bahkan dirasa cukup bebahaya dibeberapa waktu tertentu, mereka tetap memilih Pulau Kemaro sebagai salah satu tujuan wisata mereka.

Pengunjung yang datang tentunya mempunyai makna tersendiri tentang Pariwisata $\mathrm{Pu}-$ lau Kemaro. Makna Pariwisata Pulau kemaro bagi pengunjung tentunya berbeda-beda, hal ini dapat diketahui melalui pandangan, pengalaman, motif dan perilaku komunikasi yang dimiliki oleh masing-masing pengunjung, baik pengunjung yang berwisata ke Pulau Kemaro sebagai tempat wisata budaya atau tempat wisata religi. Sehingga akan menimbulkan pemaknaan yang berbeda-beda terhadap Pariwisata Pulau Kemaro itu sendiri.

Pembentukan makna adalah berfikir, dan se- 
tiap individu memiliki kemampuan berfikir sesuai dengan kemampuan dan kapasitas kognitif atau muatan informasi yang dimilikinya. Oleh karena itu, makna tidak akan sama atas setiap individu meskipun objek yang dihadapinya sama. Pemaknaan terjadi karena cara dan proses berfikir adalah sesuatu yang unik pada setiap individu yang akan menghasilkan keragaman dalam pembentukkan makna.

Beragamnya pengunjung yang datang ke Pariwisata Pulau Kemaro membuat peneliti membagi pengunjung menjadi 2 jenis, dilihat dari kegiatan yang mereka lakukan di Pulau Kemaro yang sempat tertangkap oleh peneliti pada saat pra penelitian di Pariwisata Pulau Kemaro, yaitu pengunjung yang berperan sebagai pelancong budaya dan pengunjung yang berperan sebagai pelancong religi. Selain itu, hal ini juga didukung dari hasil wawancara peneliti dengan Ibu Linda yang merupakan salah satu penjaga (kuncen) Pariwisata Pulau Kemaro:

Banyak dek yang dateng, kalo kamini (etnis Tionghoa) banyaklah yang sembahyang bae, samo kayak diklenteng-klenteng lainnyo....., tapi banyak jugo yang dateng cuma duduk bae, nyingok'i bangunan-bangunan disini terus ngumpul-ngumpul bae di deket pagoda sambil nyingok banyu sungai Musi, banyakjugo yang sering nanyo-nanyo bener dak cerito-cerito disinini.

Berdasarkan apa yang telah peneliti jelaskan di atas tentang berbagai keunikan dan daya tarik yang dimiliki oleh Pariwisata Pulau Kemaro, membuat peneliti tertarik untuk memahami dan menjelaskan tentang bagaimana pengunjung memaknai Pariwisata Pulau Kemaro serta mengetahui bagaimana perilaku komunikasi pengunjung pariwisata pulau Kemaro. Fenomena tersebut dapat dilihat dari pandangan, pengalaman, motif, dan perilaku komuniasi pelancong budaya dan pelancong religi Pariwisata Pulau Kemaro.

Pertanyaan penelitian dalam penelitian ini antara lain 1. Bagaimanakah pandangan pelancong budaya dan pelancong religi tentang Pariwisata Pulau Kemaro?, 2. Bagaimanakah pengalaman pelancong budaya dan pelancong religi tentang Pariwisata Pulau Kemaro?, 3. ApakahMotif pelancong budaya dan pelancong religi datang ke Pariwisata Pulau Kema- ro?, dan 4. Bagaimanakah perilaku komunikasi yang dilakukan diantara pelancong Pariwisata Pulau Kemaro?

\section{METODE PENELITIAN}

Menurut Guba dan Linclon (dalam Denzin, 2005) terdapat lima paradigma yang berbeda-beda sebagai landasan dasar filosofis dalam melakukan penelitian, yaitu paradigma positivis, post-positivis, kritis, konstruktivis, dan partisipatori. Penelitian ini menggunakan paradigma konstruktivisme sebagai landasan penelitian. Menurut Weber, paradigma konstruktivisme menilai perilaku manusia secara fundamental berbeda dengan perilaku alam, karena manusia bertindak sebagai agen yang yang mengkonstruksi dalam realitas sosial mereka, baik itu melalui pemberian makna atau pemahaman perilaku dikalangan mereka sendiri.

Metode penelitian yang digunakan adalah metode penelitian kualitatif. Pada dasarnya landasan teoritis dalam penelitian kualitatif bertumpu secara mendasar pada fenomenologi, dimana fenomenologi merupakan pandangan berpikir yang timbul dari rasa kesadaran untuk mengetahui, yang menekankan pada pengalaman-pengalaman subjektif manusia dan interpretasi dunia. Seperti pada penelitian ini, landasan teoritis (pendekatan) yang digunakan adalah fenomenologi (Alfred Schutz).

Fenomenologi merupakan studi mengenai manusia dalam mengalami kehidupannya di dunia. Fenomenologi melihat objek dan peristiwa dari perspektif orang yang mengalami. Realitas dalam fenomenologi selalu merupakan bagian dari pengalaman sadar seseorang. Pendekatan ini merupakan suatu langkah maju terhadap aliran yang menganggap bahwa suatu realitas terlepas dari kesadaran atau persepsi manusia.

Pendekatan fenomenologi mengasumsikan manusia sebagai makhluk yang kreatif, bekeinginan bebas, dan memiliki beberapa sifat subjektif lainnya. Fenomenologi bertujuan untuk mengetahui dunia dari sudut pandang orang yang secara langsung mengalaminya atau berhubungan dengan sifat-sifat alami pengalaman manusia, dan makna yang ditempelkan padanya. Dengan demikian penelitian fenomenologi harus menunda proses penyimpulan mengenai suatu fenomena, dengan menempatkan fenome- 
na tersebut terlebih dahulu dalam tanda kurung. Atau dengan kata lain mempertanyakan dan meneliti terlebih dahulu fenomena yang tampak, dengan mempertimbangkan aspek kesadaran yang terdapat padanya (Kuswarno, 2009: $35)$.

Fenomenologi Schutz (dalam Mulyana, 2004: 62) adalah pemahaman atas tindakan, ucapan, dan interaksi yang merupakan prasyarat bagi eksistensi sosial siapapun. Bagi Schutz, tindakan manusia adalah bagian dari posisinya dalam masyarakat, sehingga tindakan seseorang itu bisa jadi hanya merupakan kamuflase atau peniruan dari tindakan orang lain yang ada disekelilingnya. Peneliti menggunakan teknik untuk mendekati dunia kognitif objek penelitiannya. Memilih salah satu posisi yang dirasakan nyaman oleh objek penelitiannya, sehingga ia merasa nyaman di dekat peneliti dan tidak membuat bias hasil penelitian ini nantinya. Karena ketika seseorang merasa nyaman, ia akan menjadi dirinya sendiri. Ketika ia menjadi dirinya sendiri inilah yang menjadi bahan kajian peneliti.

Pemikiran Schutz bahwa bagaimana individu memahami tindakan sosial yang kemudian ditafsirkan. Proses penafsiran ini yang kemudian memperjelas dan menekankan pada makna sebenarnya, hakikat manusia dalam pengalaman subjektif, terutama ketika mengambil suatu tindakan yang akan dilakukan dan pengambilan sikap terhadap dunia sehari-hari. Schutz merumuskan esensi fenomenologi atau interaksi simbolik dalam mempelajari tindakan sosial. Schutz tertarik pada bagaimana anggota masyarakat mengendalikan kehidupan sehari-harinya, terutama pada aspek bagaimana individu secara sadar membangun makna melalui interaksi sosial, (Creswell, 1998: 53).

Asumsi ini menjelaskan bahwa pemahaman mengenai pengalaman manusia merupakan salah satu cara untuk memahami perilaku individu. Analisis fenomenologi, Merekonstruksi dunia kehidupan manusia "sebenarnya" dalam bentuk yang mereka sendiri alami dengan mempergunakan indeksikal (pemaknaan tergantung pada konteks), refleksi (mengarahkan pada kenyataan bahwa tutur kata bukan hanya tentang sesuatu, tetapi juga melakukan sesuatu), dan persediaan pengetahuan (kumpulan resep-resep (receipts) yang memberi tuntunan bagi manusia dalam berperilaku dalam suatu komunitas de- ngan kesadaran intersubjektif yang sama antar anggota masyarakat).

Dalam penelitian yang dilakukan oleh peneliti pada pengunjung Pariwisata Pulau Kemaro, yang lebih dari dua kali mengunjungi Pariwisata Pulau Kemaro ini, bertindak berdasarkan atas kesadaran dan makna Pariwisata Pulau Kemaro yang dimaknainya secara subjektif. Pemaknaan itu sendiri pun melibatkan bagaimana pengunjung melakukan interaksi dan komunikasi dengan individu lain yang juga merupakan pengunjung Pariwisata Pulau Kemaro atau penjaga/ pekerja di Pulau Kemaro.

Meminjam kata-kata Schutz bahwa tindakan manusia adalah bagian dari posisinya dalam masyarakat, sehingga tindakan seseorang itu bisa jadi hanya merupakan kamuflase atau peniruan dari tindakan orang lain yang ada disekelilingnya. Perpektif fenomenologi Alfred Schutz menjadi acuan dalam penelitian ini karena pada penelitian ini mengangkat tentang realitas kehidupan manusia dalam memaknai suatu tindakan yang dilakukan. Dalam fenomenologi Schutz merumuskan perhatiannya kepada struktur kesadaran yang diperlukan untuk terjadinya saling berinteraksi. Interaksi terjadi dan berlangsung melalui penafsiran dan pemahaman tindakan yang dilakukan baik antar individu maupun antar kelompok. Penelitian yang peneliti lakukan dilatar belakangi oleh keunikan Pulau Kemaro sebagai salah satu tempat wisata di kota Palembang yang mampu menarik banyak pengunjung. Pengunjung yang datang kerap melakukan interaksi dengan penjaga atau pekerja di Pulau Kemaro dan juga dengan pengunjung lainnya, sehingga memungkinkan pengunjung untuk membuat pemaknaan tersendiri terhadap Pulau Kemaro.

Data penelitian ini pada umumnya berupa informasi kategori substantif yang sulit di numerisasikan. Karakteristik utama dari penelitian kualitatif adalah dengan mengandalkan manusia sebagai instrumen penelitian. Karena itu, pengumpulan data dilakukan peneliti dengan cara observasi (pengamatan langsung di lapangan), wawancara mendalam, studi pustaka, dan dokumentasi.

Bila kita ingin mengenal dunia sosial, kita harus memasuki dunia tersebut (mengamati secara langsung). Kita harus hidup di kalangan manusia, mempelajari bahasanya, melihat dengan mata kepala sendiri, mendengarkan 
dengan telinga sendiri apa yang dikatakan, dan melihat sejauh mana individu memaknai sesuatu. Walaupun mengobservasi adalah kegiatan yang senantiasa kita lakukan dalam kehidupan sehari-hari, ternyata aktivitas ini tidaklah mudah, bahkan mengandung hal-hal pelik. Terutama, karena kegiatan mengamati tersebut harus senantiasa dikaitkan dengan informasi (data tentang apa yang terjadi) dan konteks (hal-hal atau situasi yang terjadi di sekitarnya).

Tujuan dari observasi ini adalah untuk memperoleh data secara langsung dalam penelitian ini disebut sebagai observasi partisipasi, dimana peneliti mengamati secara langsung dan sekaligus melibatkan diri pada situasi sosial yang sedang terjadi di Pariwisata Pulau Kemaro. Pengamatan dilakukan secara langsung terhadap fenomena sosial dan gejala sosial yang terjadi di Pulau Kemaro, baik dengan cara di rekam maupun dicatat.

Wawancara adalah bentuk komunikasi antara dua orang, melibatkan seseorang yang ingin memperoleh informasi dari orang lain dengan mengajukan pertanyaan-pertanyaan, berdasarkan tujuan tertentu. Dalam penelitian ini peneliti akan melakukan wawancara tak terstruktur dengan informan utama (pelancong budaya dan pelancong religi) dan juga informan tambahan (pelaku wisata dan pekerja di Pariwisata Pulau Kemaro).

Kegiatan wawancara dalam penelitian ini akan dikemas layaknya percakapan yang akrab. Dalam wawancara penelitian kualitatif ini, peneliti tidak mengisyaratkan sebuah pertanyaan yang dapat menghadirkan jawaban "ya" atau "tidak", dapat dikatakan dengan satu pertanyaan peneliti akan memperoleh banyak jawaban artinya peneliti memberikan kesempatan seluas-luasnya bagi informan dalam memberikan argumennya terhadap topik yang sedang dibicarakan.

Studi pustaka dilakukan terhadap berbagai literatur dan artikel yang berkaitan dengan penelitian ini untuk mengumpulkan informasi dan data pendukung yang sifatnya tertulis dan memperkuat asumsi-asumsi peneliti serta menjadi landasan teori dalam penelitian ini. Pada penelitian ini, peneliti mengumpulkan data tertulis mengenai Pariwisata Pulau Kemaro, data diperoleh melalui artikel yang dimuat oleh surat kabar atau buku yang berupa cerita rakyat. Selain itu juga data-data tertulis yang diperoleh dari pelaku wisata Pariwisata Pulau Kemaro, seperti Dinas Budaya dan Pariwisata kota Palembang.

Dokumen adalah suatu catatan kejadian yang telah terjadi. Pada penelitian ini dokumentasi juga dihimpun dari fieldnote (catatan lapangan) peneliti. Peneliti membuat catatan harian mengenai pengamatan dan temuan-temuan di lapangan sepanjang penelitian ini berlangsung. Dokumentasi merupakan penunjang data dari metode observasi dan wawancara.

Dalam menentukan subjek dalam penelitian haruslah representative, yakni mampu mewakili untuk memberikan informasi yang lengkap dan akurat. Pemilihan subjek dalam penelitian bertujuan untuk membantu peneliti agar dalam waktu relatif singkat dapat menjaring banyak informasi, karena subjek dalam penelitian dimanfaatkan untuk berbicara (menerangkan), bertukar pikiran, atau membandingkan suatu kejadian yang ditemukan dari subjek lainnya. Serta kesediaan mereka untuk mengeksplorasi dan mengartikulasikan pandangan, pengalamannya, serta motif yang mereka miliki secara sadar.

Dalam penelitian ini, peneliti menentukan beberapa kriteria yang harus dimiliki oleh $I n$ forman, yaitu individu yang berperan sebagai pelancong budaya dan pelancong religi di Pariwisata Pulau Kemaro, individu yang melakukan kontak atau interaksi langsung dengan sesama pegunjung atau petugas di Pulau Kemaro, dan individu yang memiliki peran sebagai petugas, pedagang (termasuk masyarakat), dan Pelaku wisata dalam Pariwisata Pulau Kemaro.

Ada dua jenis informan dalam penelitian ini, yaitu informan kunci dan informan tambahan. Informan kunci adalah mereka yang mengetahui dan memiliki berbagai informasi pokok yang diperlukan dalam penelitian. Key informan dalam penelitian ini adalah, pelancong budaya dan pelancong religi Pariwisata Pulau Kemaro yang representatif untuk dapat memberikan informasi yang akurat dan mendalam, serta relevan dengan fokus penelitian. Jumlah informan dalam penelitian ini tidak menjadi masalah yang besar karena yang menjadi fokus dalam studi ini adalah kelengkapan dan keakuratan data selain hasil konfirmasi peneliti terhadap subjek penelitian yang juga diikutsertakan sebagai akurasi data. Khusus untuk key informan(pelancong budaya dan pelancong religi),peneliti memiliki beberapa kriteria lain yang harus mereka miliki, 
antara lain pengunjung minimal telah dua kali melakukan perjalanan wisata ke Pulau Kemaro, pengunjung mengetahui sejarah dari Pariwisata Pulau Kemaro, pengunjung yang melakukan interaksi dengan pelaku wisata, petugas, dan wisatwan Pulau Kemaro lainnya, dan pengunjung yang memiliki tujuan khusus, seperti ziarah yang dapat kita ketahui dari kegiatan yang pengunjung lakukan selama di Pariwisata Pulau Kemaro.

Selain itu, peneliti juga memberikan kriteria khusus lainnya pada masing-masing pelancong, yaitu pelancong budaya (pelancong yang datang tidak hanya pada hari perayaan cap go meh dan pelancong yang tidak memiliki tujuan untuk bersembahyang dan pelancong religi (pelancong adalah keturunan Tionghoa/ Chinese dan pelancong memiliki tujuan utama untuk bersembahyang.

Sedangkan informan tambahan adalah individu yang terlibat langsung dalam interaksi di pariwisata Pulau Kemaro. Informan tambahan dalam penelitian ini adalah petugas, pedagang (termasuk masyarakat), serta pelaku wisata pada pariwisata Pulau Kemaro. Data yang akan didapat dari informan tambahan tidak hanya data yang berasal dari wawancara tetapi juga data tertulis, serta pengamatan secara langsung.

Penentuan informan dalam penelitian ini dilakukan dengan menggunakan prosedur purposive sampling. Prosedur purposif adalah salah satu strategi menentukan informan sesuai dengan kriteria terpilih yang relevan dengan masalah penelitian.

\section{HASIL DAN PEMBAHASAN}

Dari data hasil wawancara yang dilakukan terhadap keenam pengunjung pariwisata pulau Kemaro yang dikategorikan menjadi pelancong budaya dan pelancong religi, didapat data tentang pandangan para pelancong tentang Pariwisata Pulau Kemaro yang memiliki beberapa persamaan, sehingga dapat disimpulkan menjadi tiga pandangan terhadap pariwisata pulau Kemaro, yaitu Pulau Kemaro adalah tempat yang nyaman, memiliki nilai sejarah, dan merupakan tempat untuk bersembahyang

Dari data hasil penelitian yang telah dipaparkan sebelumnya dapat digambarkan kedalam pola pada gambar 1 .

Terdapat perbedaan jawaban yang disampaikan oleh key informan mengenai pandangan mereka tentang pariwisata pulau Kemaro, karena hal tersebut muncul dari bagaimana orang tersebut memandangnya. Pandangan tersebut dipengaruhi oleh berbagai faktor, seperti interaksi, motif dan pengalaman yang dimiliki oleh masing-masing informan terhadap pariwisata pulau Kemaro.

Moh. Ali dalam bukunya Pengantar Ilmu Sejarah Indonesia (2005), menjelaskan pengertian sejarah sebagai (1) jumlah perubahan-perubahan, kejadian atau peristiwa dalam kenyataan di sekitar kita, (2) cerita tentang perubahan-perubahan, kejadian, atau peristiwa dalam kenyataan di sekitar kita, dan (3) ilmu yang bertugas menyelidiki perubahan-perubahan, kejadian, dan atau peristiwa dalam kenyataan di sekitar kita.

Dari beberapa uraian di atas dibuat kesimpulan sederhana bahwa sejarah adalah suatu ilmu pengetahuan yang mempelajari segala peristiwa atau kejadian yang telah terjadi pada masa lampau dalam kehidupan umat manusia. Dalam kehidupan manusia, peristiwa sejarah merupakan

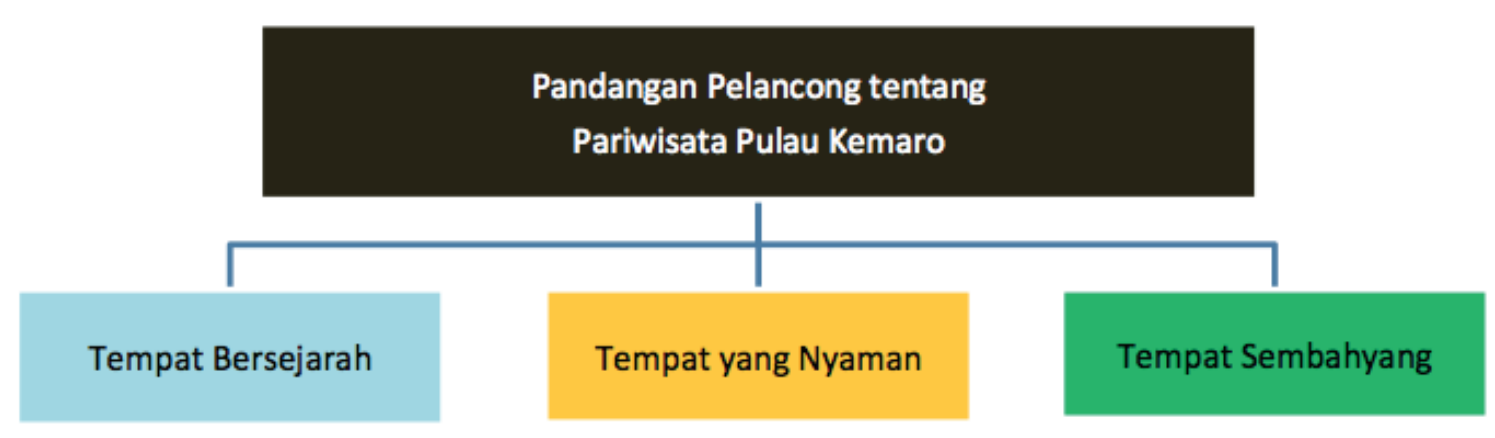

Gambar 8. 1 Pandangan Pelancong tentang Pariwisata Pulau Kemaro

Sumber: Hasil Penelitian 2013 
suatu peristiwa yang abadi, unik, dan penting. Hal ini dapat melatarbelakangi seseorang tertarik terhadap sejarah. Karena peristiwa-peristiwa penting dan unik yang terjadi di pariwisata pulau Kemaro sehingga membentuk pandangan pada diri para pelancong tentang pulau Kemaro yang dianggap sebagai tempat yang bersejarah. Karena sejarah yang melekat pada pulau Kemaro dianggap lebih dominan oleh pengunjung. Sejarah tentang Pulau Kemaro sendiri diperoleh pengunjung dari berbagai sumber, ada pelancong yang secara sengaja mencari tahu tentang sejarah pulau kemaro dengan cara membaca, ada yang mengetahui sejarah pulau Kemaro melalui cerita dari orangtua, ada juga yang mengetahui sejarahnya melalui interaksi dengan orang-orang yang ada di Pariwisata Pulau Kemaro yang sebelumnya telah mengetahui sejarah pulau Kemaro tersebut.

Pengunjung yang beranggapan bahwa pulau Kemaro adalah sebagai tempat yang nyaman diperoleh melalui pengalaman langsung yang dirasakan pengunjung ketika berada di pulau Kemaro. Nyaman menurut Kamus Besar Bahasa Indonesia adalah segar, menyegarkan, sejuk, menyejukkan. Hal ini dapat dirasakan, jika sesorang mengalaminya secara langsung. Begitu juga yang terjadi pada pengunjung
Pariwisata Pulau Kemaro yang memiliki pandangan pada pulau Kemaro sebagai tempat yang nyaman karena yang bersangkutan pernah langsug merasakan kesejukan dan ketenangan yang diberikan Pulau Kemaro sehingga membuat dirinya merasakan kenyamanan tersebut.

Sedangkan bagi pengunjung yang memiliki pandangan terhadap pariwisata pulau Kemaro sebagai tempat sembahyang dipengaruhi oleh pengalaman yang pernah dirasakan sebelumnya. Terutama bagi pelancong religi, yang secara rutin setiap tahunnya datang ke pariwisata Pulau Kemaro dengan tujuan untuk bersembahyang, akan selalu menganggap pulau Kemaro sebagai tempat untuk beribadah (sembahyang) bagi mereka.

Pandangan yang dihasilkan oleh pengunjung pariwisata pulau Kemaro tentang pariwisata pulau Kemaro tidak terlepas dari hasil interaksi individu dengan individu lain serta dengan lingkungan sekitarnya, motif tujuan yang ada pada diri setiap pengunjung, serta berdasarkan pengalaman pengunjung secara langsung yang pernah dirasakan ketika berada di Pariwisata Pulau Kemaro.

Pengalaman diartikan sebagai sesuatu yang pernah dialami (dijalani, dirasai, ditanggung)

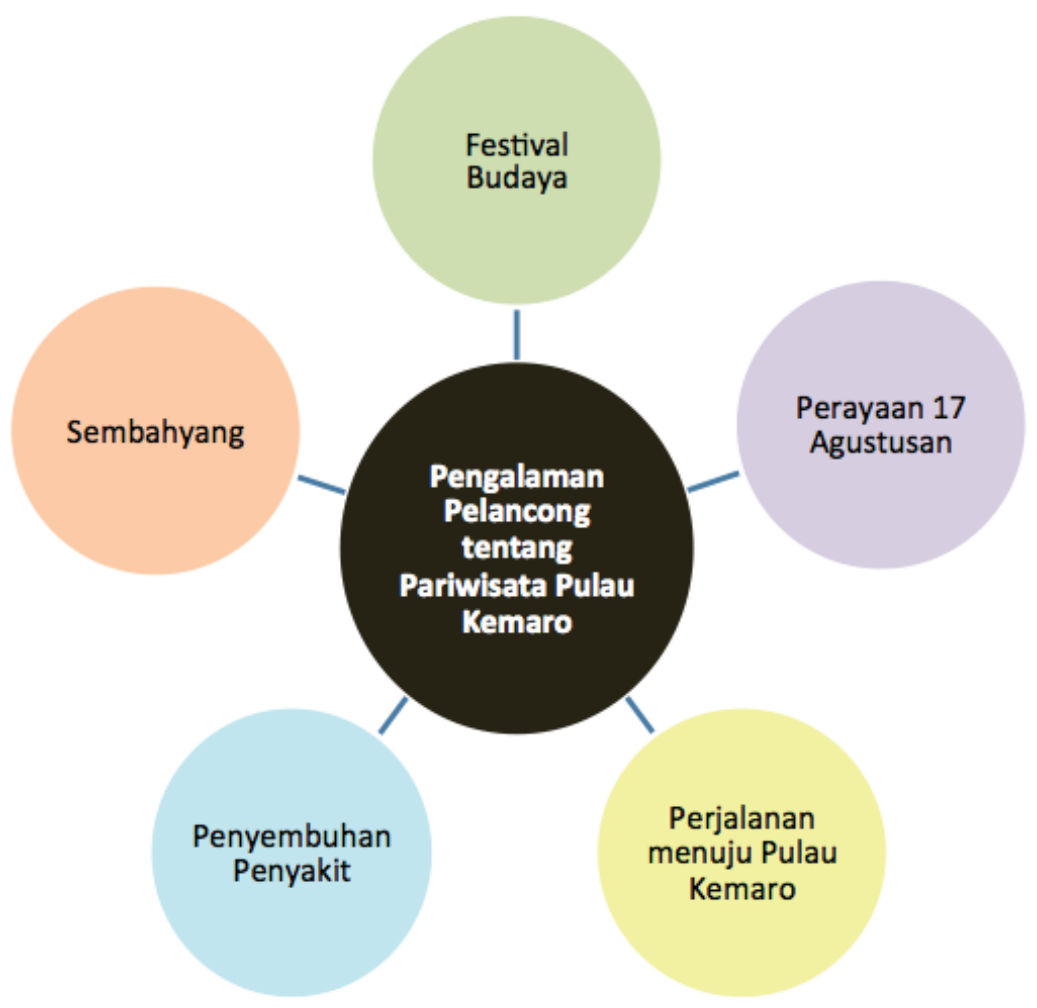

Gambar 8. 2 Pengalaman Pelancong tentang Pariwisata Pulau Kemaro

Sumber: Hasil Penelitian 2013 
menurut Kamus Besar Bahasa Indonesia (2005). Pengalaman dimiliki siapa saja untuk digunakan dan menjadi pedoman serta pembelajaran. Pengalaman tidak hanya diperoleh dari sesuatu yang telah kita lakukan, tetapi juga pengalaman dapat diperoleh dari orang lain. Oleh karena itu, banyak ilmu yang tersirat dari suatu pengalaman diri sendiri maupun orang lain sehingga menjadi suatu aset yang bernilai tinggi.

Berdasarkan pengalaman yang pernah dirasakan oleh pengunjung Pariwisata $\mathrm{Pu}$ lau Kemaro sehingga membawa pengunjung tersebut datang kembali ke pulau Kemaro. Pengalaman yang dirasakan pengunjung memberikan kesan tersendiri bagi pengunjung. Hal ini juga tidak terlepas dari proses interaksi serta motif yang melekat pada diri setiap individu (pengunjung).

Berdasarkan data yang telah peneliti kumpulkan selama proses penelitian, pengalaman yang dirasakan pelancong budaya dan pelancong religi terhadap pulau kemaro dapat digambarkan menjadi model di gambar 2 pada halaman sebelumnya. Berdasarkan yang digambarkan pada model di atas mengenai pengalaman pelancong terhadap Pariwisata Pulau Kemaro, terdapat beragam pengalaman yang dirasakan. Ada pelancong yang memiliki pengalaman yang berhubungan dengan kegiatan sembahyang di Pulau Kemaro, ada juga yang memiliki pengalaman dapat menyembuhkan penyakit setelah diobati di Pulau Kemaro. Ada pengunjung yang memiliki pengalaman lebih berkesan tentang perjalanan menuju Pulau Kemaro, karena alat transportasi yang digunakan dinilai unik dan jarang ada. Selain itu, ada juga pelancong yang memiliki pengalaman mengesankan di Pulau Kemaro ketika perayaan hari Kemerdekaan RI pada 17 Agustus, karena pada saat perayaan banyak digelar perlombaan di Pariwisata Pulau Kemaro. Terakhir, ada pelancong yang memiliki pengalaman sangat berkesan ketika perayaan Festival Budaya. Perayaan Festival budaya dilakukan pada saat perayaan Imlek bagi kaum Tionghoa.

Motif pelancong budaya dan pelancong religi datang ke Pariwisata Pulau Kemaro

Melakukan sebuah perjalanan dapat membangkitkan perasaan. Bahwa secara psikologis seseorang perlu melakukan perjalanan keluar dari rumahnya, dari lingkungan dimana dia biasa tinggal, untuk memperoleh ide-ide baru, pandangan-pandangan baru, untuk mengisi serta melengkapi kebutuhan hidupnya. Hal tersebut merupakan motivasi yang kuat untuk melakukan perjalanan. (Yoeti, 1996: 75)

Motif adalah faktor pendorong seseorang untuk bertindak atau berperilaku. Ada motif yang berasal dari proses internal, ada pula yang dari proses eksternal. Selain itu, menurut Schutz (1967: 86-96), motif dibagi menjadi dua, yaitu motif sebab atau motif alasan (because motive) serta ada pula yang disebut dengan motif tujuan biasa disebut juga motif untuk (in order to motive). Salah satu tujuan dari penelitian ini adalah untuk mengetahui motif di balik perilaku dan pengalaman informan atas kunjungannya ke pariwisata pulau Kemaro.

Pengkategorian yang telah dilakukan peneliti sejak awal adalah membagi pengunjung pariwisata pulau Kemaro menjadi dua, yaitu pelancong budaya dan pelancong religi. Jika dikategorikan menurut pemikiran Schutz, pelancong budaya dan pelancong religi yang datang ke pariwisata pulau Kemaro memiliki dua motif, yaitu motif alasan dan motif tujuan.

Pada pelancong budaya memiliki 3 motif alasan yang berbeda dari masing-masing informan, yaitu motif mencari tempat yang nyaman, karena kesenangan terhadap sejarah dan karena alasan di ajak teman. Sedangkan motif tujuan yang dimiliki pelancong budaya terdapat tiga motif berbeda, yaitu bertujuan untuk menenangkan pikiran, untuk mengetahui sejarah pulau Kemaro secara langsung dan untuk mencari kesenangan (mendapatkan kesenangan ketika berada di Pariwisata Pulau Kemaro).

Sedangkan untuk pelancong religi, masing-masing pelancong memiliki tiga motif alasan yang sama yaitu karena pertama kali pelancong religi datang ke Pariwisata Pulau Kemaro karena ajakan dari orangtua mereka, tapi pada motif tujuan terdapat dua motif yang berbeda yaitu bertujuan untuk sembahyang dan kumpul keluarga.

Berdasarkan penjelasan di atas, dan berdasarkan pengertian motif sebagai faktor pendorong seseorang untuk melakukan seseuatu, 


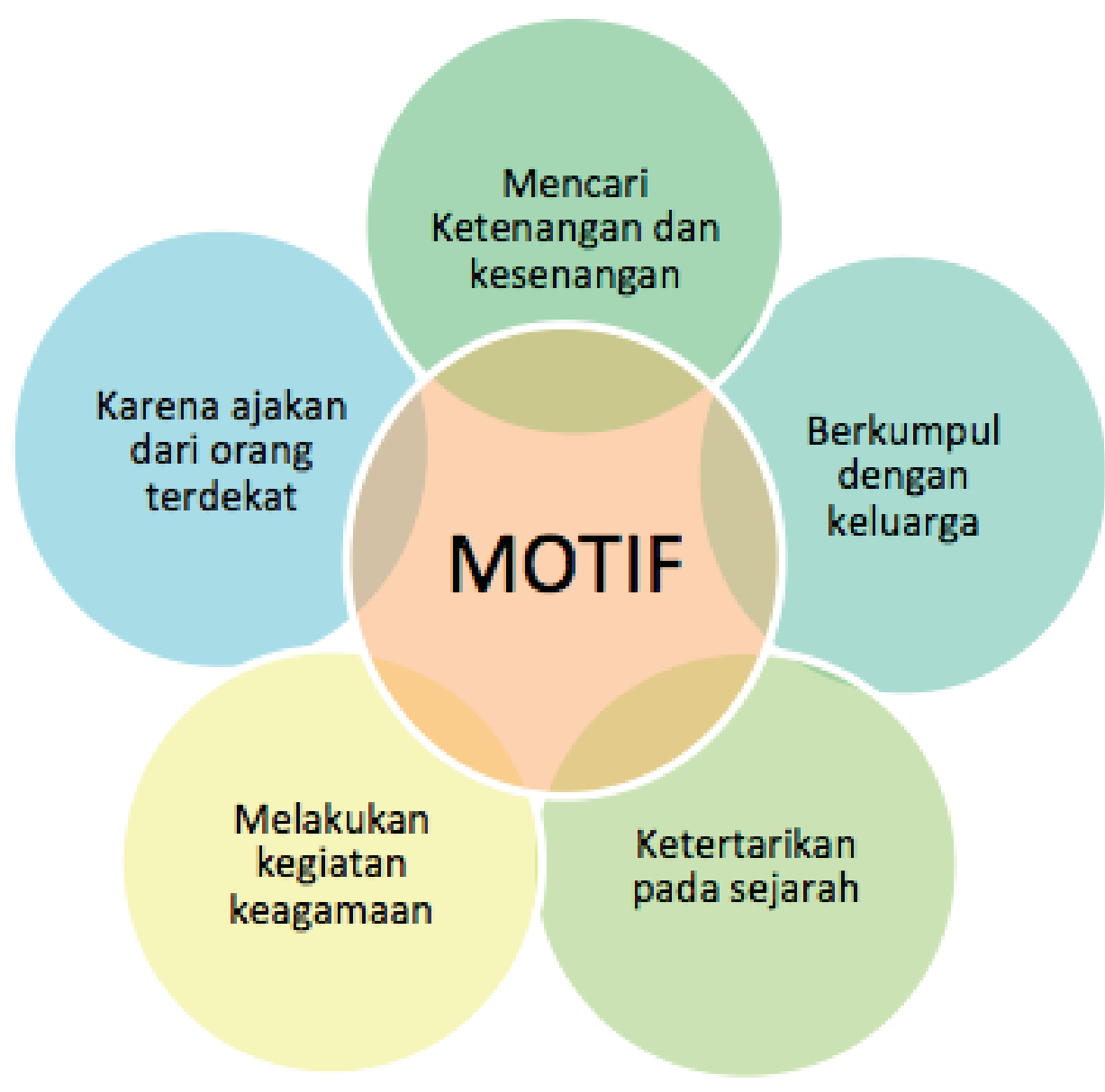

Gambar 8. 3 Motif Pelancong datang ke Pariwisata Pulau Kemaro

Sumber: Hasil Penelitian 2013

maka peneliti menarik kesimpulan bahwa motif pelancong budaya dan pelancong religi datang ke Pariwisata Pulau Kemaro karena lima motif berikut ini, yaitu: Mencari Ketenangan dan kesenangan, karena ajakan dari orang terdekat (orangtua ataupun teman), melakukan kegiatan keagamaan, ketertarikan pada sejarah, dan berkumpul dengan keluarga.

Agar lebih mempermudah dalam mengetahui motif yang dimiliki pelancong budaya dan pelancong religi datang ke Pariwisata Pulau Kemaro, peneliti membuat model mengenai motif tersebut, yaitu seperti yang tergambar pada gambar 3 di atas.

Gould dan Kolb yang dikutip oleh Ichwanudin (1998), perilaku komunikasi adalah segala aktivitas yang bertujuan untuk mencari dan memperoleh informasi dari berbagai sumber dan untuk menyebarluaskan informasi kepada pihak manapun yang memerlukan. Perilaku komunikasi pada dasarnya berorientasi pada tujuan dalam arti perilaku seseorang pada umumnya dimotivasi dengan keinginan untuk memperoleh tujuan tertentu.

Begitu juga yang terjadi di pariwisata pulau Kemaro. Interaksi dilakukan diantara pengunjung dengan pengunjung atau antara pengunjung dengan pelaku wisata di pariwisata pulau Kemaro karena memiliki tujuan, yaitu untuk mendapatkan informasi. Akan tetapi, selain tujuan untuk mendapatkan informasi yang melatarbelakangi pengunjung melakukan interaksi karena telah saling mengenal dan terdapat kedekatan diantara satu sama lain.

Berdasarkan data yang telah dikumpukan, maka peneliti membuat model tentang interaksi yang terjadi di pariwisata pulau Kemaro, yaitu: Gambar 4 adalah model interaksi yang tejadi di antara pelancong dengan pelancong lainnya dan diantara pelancong dengan pelaku wisata. Perilaku komunikasi interpersonal pada pengunjung pariwisata pulau Kemaro berlangsung secara dominan dengan pengunjung lainnya serta dengan pelaku wisata pariwisata pulau Kemaro. Perilaku komunikasi interpersonal sendiri berlangsung dalam situasi yang 


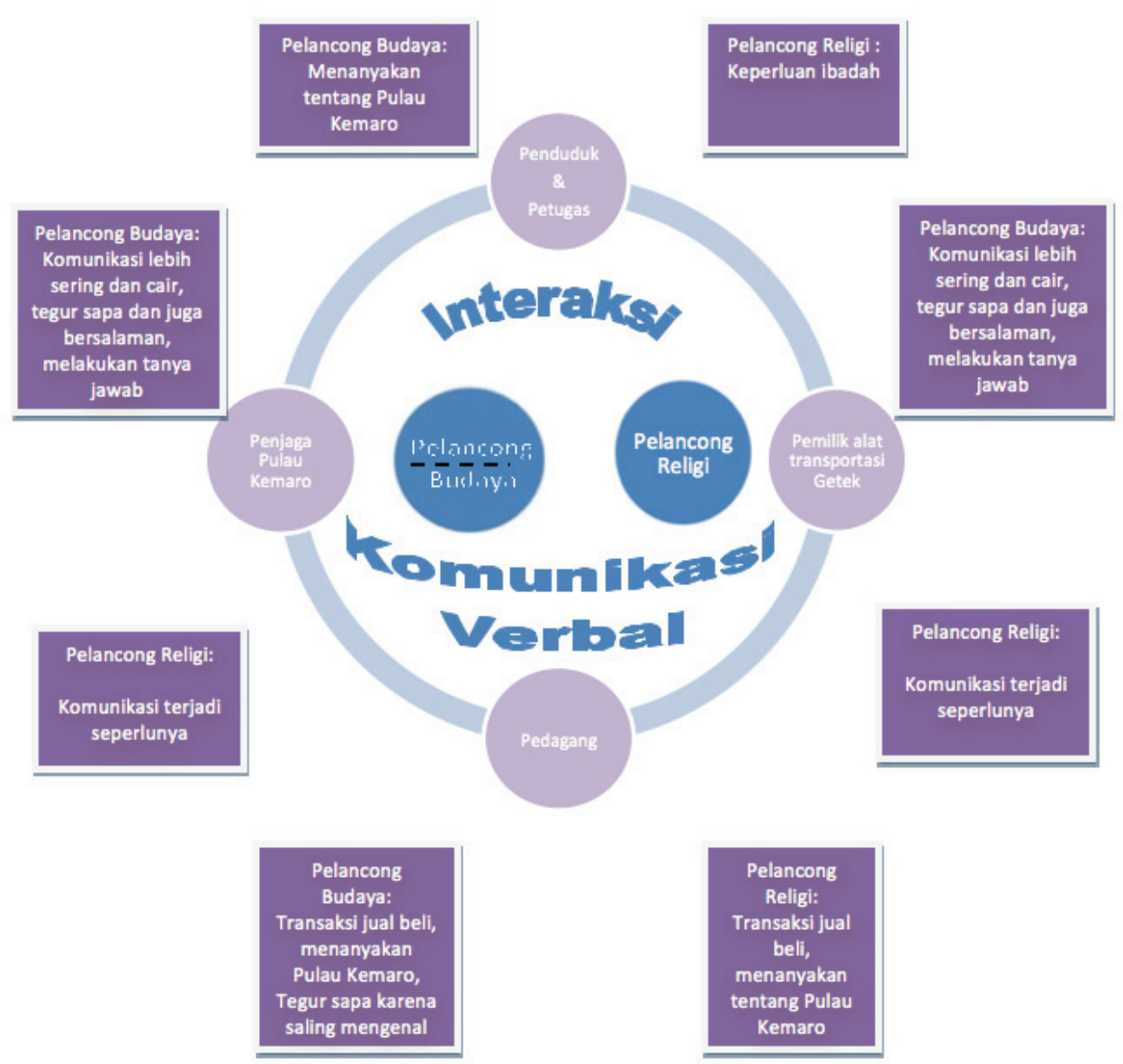

Gambar 8. 4 Model Perilaku Komunikasi Pelancong di Pariwisata Pulau Kemaro Sumber: Hasil Penelitian 2013

menyenangkan dan santai. Komunikasi interpersonal melalui interaksi yang berlangsung diantara sesama pengunjung atau diantara pengunjung dengan pelaku wisata disesuaikan dengan kondisi kepentingan yang dirasakan.

\section{SIMPULAN}

Berdasarkan dari hasil dan pembahasan yang telah diuraikan pada bab sebelumnya, maka diperoleh simpulan mengenai pandangan, pengalaman, motif, serta perilaku komunikasi pengunjung pariwisata pulau Kemaro berikut ini.

Terdapat beragam pandangan yang diberikan pengunjung tentang pariwisata pulau Kemaro, antara lain sebagai tempat yang bersejarah, tempat yang nyaman, dan tempat untuk sembahyang.

Pengalaman pelancong yang diperoleh selama berada di pulau Kemaro, yaitu sembahyang, festival budaya, perayaan 17 Agustusan, perjalanan menuju pulau Kemaro, dan penyembuhan penyakit.

Ada motif yang melekat pada diri individu yang datang sebagai pengunjung di Pariwisata Pulau Kemaro. Berdasarkan kategori motif dari para pakar yang telah dijelaskan pada bab sebelumnya, dan berdasarkan pengertian motif sebagai factor pendorong seseorang untuk melakukan seseuatu, maka peneliti menarik kesimpulan bahwa motif pelancong budaya dan pelancong religi dating ke Pariwisata Pulau Kemaro, yaitu: mencari ketenangan dan kesenangan, karena ajakan dari orang terdekat (orangtua atau pun teman), melakukan kegiatan keagamaan, ketertarikan pada sejarah, serta untuk berkumpul dengan keluarga.

Perilaku komunikasi adalah segala aktivitas yang bertujuan untuk mencari dan memperoleh informasi dari berbagai sumber dan untuk menyebarluaskan informasi kepada pihak manapun yang memerlukan. Bentuk perilaku komunikasi yang terjadi di Pariwisata Pulau Kemaro adalah interaksi yang terjadi diantara pengunjung serta diantara pengunjung dengan pelaku wisata. Interaksi dilakukan karena terdapat tujuan yang ingin dicapai yaitu untuk mendapatkan informasi. Bentuk interaksi yag 
terjadi yaitu komunikasi secara verbal.

Berdasarkan pemaparan keempat poin diatas yaitu tentang pandangan, pengalaman, motif serta perilaku komunikasi pengunjung pariwisata pulau Kemaro dapat disimpulkan bahwa makna pariwisata pulau Kemaro menurut salah satu pengunjung yaitu sebagai tempat bagi warga Tionghoa untuk bersembahyang, serta salahsatu tempat wisata yang nyaman di kota Palembang yang memiliki nilai sejarah yang tinggi.

Pada penelitian ini, hanya terbatas pada pencarian makna yang diberikan pelancong budaya dan pelancong religi tentang pariwisata pulau Kemaro bersadarkan pada pandangan dan pengalaman subjektif individu. Sehingga dikaji menggunakan pendekatan fenomenologi. Akan tetapi pulau Kemaro tidak hanya berkutat tentang bagaimana individu dalam memaknai pariwisata pulau Kemaro, akantetapi banyak fenomena yang berkaitan dengan pariwisata pulau Kemaro yang dapat dikaji melalui kajian ilmu sosial lainnya, dari segi agama juga termasuk tentang mitos yang ada di pariwisata pulau Kemaro. Penelitian selanjutnya dapat menggunakan pendekatan yang berbeda denagn penelitian yang telah dilakukan atau dari kajian teori-teori yang berbeda pula.

Pariwisata Pulau Kemaro saat ini mulai ramai diperbincangakan dan banyak pengunjung yang mendatangi pulau Kemaro. Untuk itu, Pemerintah Kota Palembang, khususnya Dinas Kebudayaan dan Pariwisata kota Palembang, Yayasan Pariwisata Pulau Kemaro dan penjaga Pulau Kemaro untuk lebih memperhatikan sarana dan prasarana yang dibutuhkan bagi wisatawan serta menambah fasilitas lain yang dapat menunjang pulau Kemaro dalam mendatangkan wisatawan. Sehingga, semakin banyak wisatawan yang berwisata ke pulau Kemaro akan menambah pemasukan bagi pemerintah, juga dapat membantu perekonomian, khususnya pelaku wisata di pulau Kemaro.

\section{DAFTAR PUSTAKA}

Creswell, W. J. (1998). Qualitative inquiry and research design, choosing among five tradition. Sage Publications

Denzin, N. K dan Lincoln, Y. (2005). "The SAGE handbook of qualitative research" (4th ed). Thousand Oaks, Sage Publication.

Kuswarno, E. (2009). Metode penelitian komunikasi: fenomenologi, konsepsi, pedoman dan contoh penelitian. Bandung: Widya Padjadjaran.

Moh, R. A. (2005). Pengantar Ilmu Sejarah Indonesia. Yogyakarta: PT LKiS Pelangi Aksar

Mulyana, D. (2004). Metode penelitian kualitatif: paradigma baru Ilmu Komunikasi dan Ilmu Sosial lainnya. Bandung: Remaja Rosdakarya.

Yoeti, O. A. (1996). Pengantar Ilmu Pariwisata. Bandung: Angkasa.

Schutz, A. (1967). The phenomenology of the social world, terj. George Walsh, Northwestern University Press.

Ichwanudin. (1998). Hubungan perilaku komunikasi peserta kelompok penggerak pariwisata (Kompepar) dengan adopsi program sapta pesona di Kabupaten Sukabumi. Tesis, Sekolah Pasca Sarjana-Jurusan Komunikasi Pembangunan Pertanian. Bogor: Institut Pertanian Bogor.

Kamus Besar Bahasa Indonesia. (2005).

Palembang, An International, Prosperous \& Cultured City (2013) The City Government of Palembang.

Sumatra Ekspres. Sabtu, 23 Februari 2013. 